\title{
A Comparison of Bird Damage Among Eleven Varieties of Corn in Haiti ${ }^{1}$
}

\author{
Richard M. Engeman ${ }^{2}$, Jean-Paul Samedy ${ }^{3}$, Michael S. Bornstein ${ }^{2}$, and \\ G. Clay Mitchell ${ }^{2}$
}

\section{ABSTRACT}

Because corn is the major food crop grown in Haiti, a study was conducted to compare bird damage among 11 nonhybrid varieties including the traditional corn preferred by Haitians. The effect of fertilizer on damage levels was also examined. Damage measurements analyzed were proportion lost by surface area and weight. No differences among variety, fertilization, nor variety by fertilization interaction, were detected statistically for either variable. Baseline damage levels were high (overall average of $9 \%$ versus less than $1 \%$ in midwestern U.S.) with much variation throughout the variety by fertilization combinations. We speculate that the patchy nature of bird damage may have decreased the sensitivity of the analyses to differences among the varieties. In any case, damage levels generally were high for each variety.

\section{INTRODUCTION}

Corn is the major food crop grown in Haiti. Production in 1979 was $183,000 \mathrm{t}$ as compared with $123,000 \mathrm{t}$ of millet and $122,000 \mathrm{t}$ of rice (5). The traditional preferred corn grown in Haiti is a nonhybrid variety called Chicken Corn, which is a poor producer with a thick husk comprised of 15-20 leaves. Haitian farmers believe that this thick husk is a deterrent to rodent and bird depredation.

The Ministry of Agriculture/Haiti and Texas A\&M University have a joint project with the objective of increasing the production of basic food crops on small farms (2). Within this objective, various nonhybrid varieties of corn are being evaluated on the basis of yield, other agronomic characteristics, and resistance to vertebrate pests.

This paper presents results from field trials in which 11 varieties of nonhybrid corn are compared for bird depredation. Information on yields and acceptance by a tasting panel are referenced to assist in determining an optimal variety.

\section{MATERIALS AND METHODS}

Ten nonhybrid varieties were recommended for testing by the International Center for the Improvement of Corn and Wheat (CIMMYT): Poza Rica 7427, Across 7726, Poza Rica 7726, La Máquina 7827, Siete

${ }^{1}$ Manuscript submitted to Editorial Board May 11, 1984.

This research was supported by funds provided to the U.S. Fish and Wildlife Service by the U.S. Agency for International Development under PASA ID/LAR-0594-2-79.

${ }^{2}$ Denver Wildlife Research Center, Building 16, Federal Center, Denver, Colorado 80225.

${ }^{3}$ Vertebrate Pest Control Project, Ministry of Agriculture, P.O. Box 330, Port-au-Prince, Haiti. 
Lagos 7728, Proa Rica 7928, Levy 7835, Tocumen 7926/1, Tocumen 7931/1 and La Máquina 7928. Two local varieties were also tested: Chicken Corn and Les Anglais. One variety, Tocumen 7931/1, was eliminated from the study because the damage data was not collected properly.

The study was conducted at the Haitian Ministry of Agriculture Experimental Station near Port-au-Prince. A field $(60 \mathrm{~m} \times 32 \mathrm{~m})$ was partitioned into four blocks (replicates). Each block was divided in half, with one half receiving fertilizer and the other half remaining unfertilized. For each variety of corn studied, a plot was planted in each of the fertilized and unfertilized halves of each block.

The main vertebrate pests identified in maturing corn were Norway rats (Rattus norvegicus), African village weavers (Ploceus cucullatus), Hispaniolan woodpecker (Melanerpes striatus), and Hispaniolan parakeets (Anatinga chloroptera). A suspect species was the glossy cowbird (Molothrus bonariensis). Because we were exclusively studying bird damage, rodents were controlled in the field by applying sustained baits with anticoagulant rodenticides as described by Benigno et al. (1). The only deviation from this procedure was the use of cracked corn instead of rice shorts as the bait carrier. Preharvest losses to rodents on the research plots were minimal; the proportion lost overall was 0.005 with a standard error of 0.001 , indicating nearly complete control. No attempts were made to displace birds feeding in the field.

Damage measurements were made on every ear of corn in one of the outer two of four rows in each plot (1585 total ears). The corn plants in the other rows were used for studies on yield and other agronomic variables. The measurements taken on each ear included length, number of rows of kernels, and length within each row that had been damaged by each kind of vertebrate pest. This allowed for an estimate of the proportion of the surface area damaged on each ear to be made.

With an independent sample of 200 undamaged ears, three regression analyses were performed to determine the relation between weight of corn and ear length for each of the base, middle, and tip thirds of the ears. These relations provided a means by which the proportion of the total weight lost from each ear could be estimated.

In addition to yield, Texas A\&M personnel also conducted a palatability test with 12 Haitian farmers and their wives (2). The fineness of grinding and taste after cooking were rated by each of the 24 individuals as "good" or "inferior."

\section{RESULTS AND DISCUSSION}

An analysis of variance for a two-factor experiment in a randomized block design was performed on each of the two variables measured for 
each ear: proportion of surface area lost, and proportion of weight lost. Since we were analyzing proportional data, the above two variables were reanalyzed after applying the arcsine square root transformation (e.g., $3)$, to stabilize the variance and normalize the data. Because the results were essentially the same for the original and transformed data, only the results from analyzing the original data are presented here.

Table 1 presents the $p$ values for the main effects and interaction from the analyses of variance performed on proportion of surface area lost and proportion of weight lost. The mean proportions lost for surface area and

TABLE 1.-ANOVA P-Values from ANOVAs on surface area lost and weight lost

\begin{tabular}{lccc}
\hline \multirow{2}{*}{ Source } & df & \multicolumn{2}{c}{ Variable } \\
\cline { 3 - 4 } & & Surface area lost & Weight lost \\
\hline Variety & 1 & .40 & .38 \\
Fertilizer & 10 & .34 & .36 \\
Variety $\times$ fertilizer & 10 & .43 & .42 \\
\hline
\end{tabular}

TABLE 2.-Mean percentages of bird damage by area and weight for variety, fertilizer, variety $\times$ fertilizer interaction

\begin{tabular}{|c|c|c|c|c|c|c|}
\hline \multirow{2}{*}{ Variety } & \multicolumn{2}{|c|}{ Fertilized } & \multicolumn{2}{|c|}{ Unfertilized } & \multicolumn{2}{|c|}{$\begin{array}{l}\text { Means across } \\
\text { fertilization }\end{array}$} \\
\hline & Area & Weight & Area & Weight & Area & Weight \\
\hline Across 7726 & .1067 & .0997 & .0596 & .0550 & .0844 & .0785 \\
\hline Chicken Corn & .0925 & .0839 & .0706 & .0660 & .0840 & .0770 \\
\hline La Máquina 7827 & .1244 & .1175 & .0492 & .0433 & .0926 & .0861 \\
\hline La Máquina 7928 & .1319 & .1267 & .1122 & .1059 & .1213 & .1155 \\
\hline Les Anglais & .1220 & .1158 & .0951 & .0908 & .1076 & .1024 \\
\hline Levy 7835 & .0380 & .0347 & .0795 & .0740 & .0563 & .0520 \\
\hline Poza Rica 7427 & .1337 & .1270 & .0720 & .0666 & .1032 & .0972 \\
\hline Poza Rica 7726 & .0889 & .0840 & .0703 & .0642 & .0790 & .0735 \\
\hline Poza Rica 7928 & .0923 & .0879 & .1012 & .0965 & .0964 & .0918 \\
\hline Siete Lagos 7728 & .1279 & .1200 & .1002 & .0946 & .1141 & .1074 \\
\hline Tocumen 7926/1 & .1011 & .0953 & .0882 & .0841 & .0953 & .0904 \\
\hline Means across varieties & .1045 & .0984 & .0820 & .0767 & .0938 & .0881 \\
\hline
\end{tabular}

weight for each of the variety-fertilizer combinations are presented in table 2. For both variables, no differences were detected among the levels of variety, fertilizer nor variety by fertilizer interaction (table 1). Perhaps real differences do not exist among the levels of these effects, but the patchy nature of bird damage in a field could also cause a great deal of variability in losses among the blocks and, therefore, cause a field experiment of this size to be insensitive to real differences. A larger study may be required to detect these possible differences. 
The values in the body of table 2 indicate bird damage losses ranging from 3.8 to $13.4 \%$ for surface area and from 3.5 to $12.7 \%$ for weight. Even though the fertilization by variety interaction was not significant, these values indicate considerable variation among variety by fertilizer combination, but usually with a substantial level of damage in the cells. Similarly, the mean damage levels of varieties over fertilization range from 5.6 to $12.1 \%$ for surface area, and 5.2 to $11.6 \%$ for weight. Coincidentally, the varieties eliminated (Across 7726, Levy 7835, Poza Rica 7726) by the Texas A\&M study on yields, palatability and earliness (2) were generally also those with the lowest bird damage (although no loss differences among varieties were statistically detectable). Perhaps, some of the qualities that make a variety less desirable to humans, also influence birds. The two local varieties were outproduced by each of the varieties recommended by CIMMYT (2) and also had some of the higher damage levels.

The overall damage levels were $9.4 \%$ by area and $8.8 \%$ by weight. These figures are in sharp contrast to those for Ohio, Kentucky, and Tennessee, where average losses for each state were less than $1 \%$ by surface area (4). These values plus those discussed in the preceeding paragraph demonstrate substantial depredation from birds on corn, regardless of the variety. Possibly a larger study would indicate which, if any, of these varieties is more resistent to bird damage. Even if one or more varieties prove superior for resisting bird damage and also have acceptable palatability and growth characteristics, this study indicates that depredation from birds could still result in substantial losses of this subsistence crop. In addition to further varietal testing, research should also be focused on methods to prevent or alleviate bird damage in Haitian crops.

\section{RESUMEN}

Un estudio se realizó para comparar el daño causado por pájaros a 11 variedades de maíz incluyendo la tradicional preferida en el pais. El efecto de los abonos con referencia a los suelos en que ocurrió el daño, también se estudió. La medida de los daños causados fue proporcional a la pérdida de superficie en área y peso. No se encontraron diferencias estadísticas entre las variedades de maíz, abonos o interacciones de variedades y fertilizantes.

La medida del daño a los suelos fue alta (un medio de $9 \%$ comparado con menos de $1 \%$ en el medio oeste de los Estados Unidos) con variaciones entre las diferentes combinaciones entre variedades y abonos. Creemos que las manchas aisladas dejadas por los pájaros pueden haber disminuido la sensibilidad de los análisis de diferencias entre variedades. De todas 
maneras, los daños causados fueron generalmente muy altos en cada variedad.

\section{LITERATURE CITED}

1. Benigno, E. A., R. A. Reidinger, J. L. Libay and F. F. Sanchez, 1976. Sustained baiting with anticoagulant rodenticides in corn fields and assessment of rat damage. Proceedings 7th National Pest Control Conference, Los Baños, Philippines; 7: 146.

2. Cheaney, R. L., 1982. Progress Report of the Research and Extension Component of the Integrated Agricultural Development Project, International Program Department Haiti Team of Texas A\&M University.

3. Snedecor, G. W. and W. G. Cochran, 1980. Statistical Methods, Iowa State University Press, Ames, Iowa.

4. Stickley, A. R., Jr., D. L. Otis, and D. T. Palmer, 1979. Evaluation and results of a survey of blackbird and mammal damage to mature field corn over a large (threestate) area. Vertebrate Pest Control and Management Materials, ASTM STP 680, J. R. Beck, Ed, American Society for Testing and Materials, 169-77.

5. 1979. Total Production of Crops in Haiti. Office d'Économie Rurale de Statistiques Agricoles, Departement de l'Agriculture, des Resources Naturelles et du Développement Rural. 